\title{
MARKETING COMMUNICATION PT BODDIA JAYA DALAM MENGGAET FUNDING LUAR NEGERI
}

\author{
Ramsiah Tasruddin dan Usti Arung Sari \\ Ilmu Komunikasi Fakultas Dakwah dan Komunikasi UIN Alauddin Makassar \\ Email : ramsiah.tasruddin@gmail.com
}

\begin{abstract}
This study aims to understand PT.Boddia Jaya's marketing communication model in attracting foreign parties. In addition, it is also to find out the obstacles experienced by PT.Boddia Jaya's company when communicating with foreign parties. The source of research data is the marketing division, Quality Control, and Front Desk of PT.Boddia Jaya. Data collection techniques namely observation and interviews. The results of research conducted at PT. Boddia Jaya can be concluded that there are three marketing communication strategies for foreign parties, namely Advertising, Advertising (by email) and Packaging (packaging). The strategy carried out by this company has been around since it first exported abroad. Even so, the three strategies that were carried out in establishing cooperation between PT.Boddia Jaya with foreign parties also experienced obstacles in communication. This is due to cultural and linguistic differences and also the great distances that make marketing communication between the two parties ever hampered. To overcome these obstacles, both parties learn each other's language and culture.
\end{abstract}

Keywords: marketing communication, strategies, PT Boddia Jaya

\section{A. PENDAHULUAN}

Sebuah perusahaan atau organisasi ketika membina hubungan antara pihak internal/external perlu dijalin dengan baik dan harmonis. Adanya tujuan yang sama yang dimiliki oleh seluruh pihak di bawah naungan perusahaan maupun pihak di luar perusahaan. Tujuan yang ingin dicapai bisa berupa keuntungan dari sebuah produk perusahaan dan reputasi/image yang baik perusahaan atau organisasi. Jika kedua tujuan tersebut tercapai,maka perusahaan bisa lebih memperluas jaringan atau target sasaran (stakeholder) demi keberhasilan dan kemajuan perusahaan atau organisasi.

Perusahaan atau organisasi dapat memperluas kerjasama dengan pihak luar jika dibantu dengan praktisi public relations, meskipun perusahaan atau organisasi tidak menetapkan posisi public relations dalam struktur organisasi setidaknya dalam perusahaan tersebut melakukan aktivitas public relations. Tujuan aktivitas public relations adalah untuk mengkomunikasikan kepada publik, pelanggan dan stakeholder mengenai informasi perusahaan, produk, citra perusahaan dan membina hubungan kerja sama yang baik dan secara terus menerus. Public 
relations sebagai fungsi manajemen dalam membantu organisasi, institusi, atau perusahaan. Fungsi yang dimaksud adalah public relations melakukan sesuatu berupa tindakan kepada publik untuk mendapatkan perhatian dan dukungan. ${ }^{1}$

Perusahaan yang melakukan aktivitas public relations akan memiliki fungsi manajemen yang kuat. Hal tersebut akan membantu perusahaan untuk mendapatkan keuntungan. Aktivitas public relations yang dimaksud adalah bisa berupa strategi yang dilakukan oleh divisi yang telah ditentukan untuk mencapai keuntungan dan mendapatkan citra yang baik dari pelanggan maupun stakeholder.

Perusahaan akan menentukan target sasaran (stakeholder) untuk keberhasilan dan tercapainya tujuan perusahaan atau organisasi. Jika perusahaan yang menghasilkan suatu produk/barang,maka stakeholder nya adalah perusahaan yang bergerak dibidang yang sama yaitu memproduksi barang. Jika perusahaan atau organisasi yang bergerak dalam pelayanan atau jasa, maka stakeholder nya bisa masyarakat secara umum atau perusahaan tertentu (misalnya, perusahaan pengantar barang). Hal utama yang dilakukan untuk menjalin kerja sama dengan publik dan stakeholder,yaitu kapasitasnya dalam mengelola informasi,kapasitas dalam melakukan pencitraan terhadap seluruh aktivitas komunikasi, kapasitas bernegosiasi dengan pihak tertentu (stakeholder). ${ }^{2}$ Penelitian yang dilakukan oleh peneliti mengenai Strategi komunikasi pemasaran sebuah perusahaan dalam menjalin kerjasama dengan pihak luar negeri. Perusahaan yang akan dijadikan sebagai lokasi penelitian dalam penelitian. PT Boddia Jaya merupakan perusahaan yang memproduksi hasil laut yaitu telur ikan. Perusahaan ini sudah memiliki kerjasama dengan stakeholder yang ada di luar negeri,yaitu beberapa Negara seperti China,Jepang dan Korea.

Perusahaan yang sudah memiliki stakeholder luar negeri, maka aktivitas public relations dalam menjalin kerjasama yang baik sudah mengetahui bentuk komunikasi bisnis silang budaya. Budaya yang dimaksud adalah karakter stakeholder luar negeri dalam menjalin kerjasama dengan perusahaan. Dalam menjalin kerjasama dengan pihak luar, sebuah perusahaan tentu memiliki strategi untuk mendapatkan tujuan dan keuntungan. Ranah komunikasi bisnis silang budaya, hal yang perlu dilakukan demi kesuksesan kerjasama stakeholder, yaitu mengenali karakteristik budaya ,strategi mengatasi perbedaan budaya dan bahasa,mengetahui strategi dan

\footnotetext{
${ }^{1}$ Syarifuddin S.Gassing dan Suryanto,"public relation”,(Yogyakarta:Penerbit Andi Yogyakarta,2016), hlmn 8

${ }^{2}$ Morissan, “manajemen public relation”,(Jakarta:Kencana,2010),hlmn 1
} 
taktik negosiasi,dan mengetahui etika bisnis global. ${ }^{3}$ Hal tersebut perlu diketahui untuk menghindari hambatan dalam berkomunikasi dengan pihak luar. Hambatan bisa memengaruhi proses pemasaran dalam perusahaan, khususnya dalam memasarkan produk. Selain hambatan bahasa, budaya yang berbeda cenderung menimbulkan stereotip antara kedua belah pihak (perusahaan dan pihak luar). Untuk itu perlu mempelajari penyebab terjadinya hambatan sebelum menjalin kerjasama atau memasarkan produk.

\section{B. TINJAUAN PUSTAKA}

\section{Relasi Public Relations}

Public relations adalah penyelenggara komunikasi timbal balik (two way communication) antara organisasi/perusahaan dengan publik yang bertujuan untuk menciptakan sikap saling pengertian dan dukungan bagi tercapainya suatu tujuan tertentu, kebijakan, kegiatan produksi. Demi kemajuan perusahaan/organisasi atau untuk meraih citra positif. Public relations juga erat kaitannya dengan pembentukan opini publik dan perubahan sikap dari publik. ${ }^{4}$

Public relations memiliki objek dan subjek yaitu kelompok masyarakat yang penting bagi perusahaan/organisasi. Kelompok masyarakat ini disebut publik eksternal. Setiap perusahaan/organisasi memiliki publik khususnya. Untuk itu, komunikasi yang dijalin bukan hanya dengan staf atau pegawai yang ada dalam perusahaan. Ada beberapa publik yang diutamakan oleh perusahaan/organisasi, sebagai berikut: ${ }^{5}$

1) Masyarakat umum

2) Calon pegawai/anggota

3) Pegawai/anggota

4) Mitra usaha/pemasok

5) Investor,perbankan,pemegang saham

6) Distributor

7) Konsumen

8) Pemimpin

9) Pemerintah. ${ }^{6}$

\footnotetext{
${ }^{3}$ Muhammad Budyatna, “komunikasi bisnis silang budaya”,(Jakarta:Kencana,2012),hlmn 50-132

${ }^{4}$ Alimuddin Ramli, "aktivitas bagian humas secretariat daerah kab.luwu sebagai fungsi mediataor dan publisitas”, jurnal poplicus, tahun 1, No.1,januari-juni 2016, h.123

${ }^{5}$ M.Linggar Anggoro, ”teori da profesi kehumasan (serta aplikasinya di Indonesia”,(Jakarta:PT Bumi Aksara,2008)h.19

${ }^{6}$ M.Linggar Anggoro, ”teori da profesi kehumasan (serta aplikasinya di Indonesia”,(Jakarta:PT Bumi Aksara,2008)h.20
} 
Perusahaan dimana Public relations harus menghandle banyak hal adalah sistem. Satu dan lainnya saling terkait, manusia-mesin-aturan. Di antara ketiga elemen sistem tadi yang paling rawan berubah adalah manusia. Disinilah pentingnya aktivitas Public relations dalam memaknai apa yang dihadapinya sebagai sistem. Satu prinsip yang harus dipegang dan diingat adalah tidak ada segala sesuatu yang berjalan sendiri,semuanya terikat dalam mata rantai sebab akibat. ${ }^{7}$

1. Fungsi public relations dalam perusahaan

Posisi atau bidang Public relations dalam organisasi maupun perusahaan berperan penting untuk perkembangan organisasi dan citra yang baik. Public relations memberi kontribusi besar terhadap pencapaian tujuan sebuah organisasi atau perusahaan.

"Edward L. Bernays mengungkapkan ada tiga fungsi Public relations dalam organisasi. Pertama, memberikan penerangan kepada publik. Kedua, membujuk publik untuk mengubah sikap dan tindakan. Ketiga, berusaha mempresentasikan sikap organisasi terhadap publik dan sebaliknya."

Public relations perlu memiliki kemampuan berkomunikasi dalam menjalankan tugasnya sebagai mediator perusahaan/organisasi. Selain itu, fungsi utama Public relations adalah mengontrol sikap organisasi (internal) sebelum mengubah sikap dan tindakan publik di luar organisasi/perusahaan. Fungsi manajemen Public relations dalam rangka mencapai tujuan organisasi atau perusahaan menjadi hal penting yang menjadi tugas PR itu sendiri. Beberapa fungsi manajemen dalam kegiatan Public relations,yaitu: ${ }^{9}$

a. Menganalisis opini dan sikap publik terkait isu yang memengaruhi rencana organisasi.

b. Memberikan saran kepada manajemen berkaitan dengan pengambilan keputusan hingga mengukur tanggung jawab sosial organisasi

c. Melakukan riset, mengawasi melaksakan program kerja,dan ikut melakukan evaluasi secara rutin. Kegiatan ini meliputi program marketing,finansial dan menjaga komunikasi berbagai pihak.

d. Turun secara aktif dalam implementasi program kerja organisasi untuk mengubah kebijakan publik.

\footnotetext{
${ }^{7}$ Herien Priyono, “public relation sebagai strategic tools”,(Jogjakarta:UII Press,2005),h.49

${ }^{8}$ Syarifuddin S.Gassing dan Suryanto, ”public relation”,(Yogyakarta:Penerbit Andi Yogyakarta,2016), hlmn

${ }^{9}$ Syarifuddin S.Gassing dan Suryanto, ’public relation”,(Yogyakarta:Penerbit Andi Yogyakarta,2016), hlmn 
e. Ikut serta menyumbangkan nasihat terkait rekruitman dan pelatihan staf. Praktisi Public relations juga berfungsi mengelola sumberdayaTurut mendefinisikan dan mengimplementasikan kebijakan menggunakan keahlian komunikasi. ${ }^{10}$

Jika perusahaan/organisasi mengalami situasi yang sulit dalam mengatasi masalah, maka Public relations yang menjadi senjata bagi perusahaan/organisasi untuk mengatasi segala masalah dan ancaman. Public relations hendaknya selalu siap jika terjadi permasalahan yang bisa menyebabkan perusahaan/organisasi mengalamai kerugian finansial dan reputasi yang akan buruk.

\section{Komunikasi Bisnis}

Kemajuan teknologi komunikasi secara otomatis mempermudah dalam proses interaksi meskipun tidak mengharuskan tatap-muka (face to face). Namun, tidak berarti komunikasi tatap muka tidak penting lagi, bentuk komunikasi inilah yang paling sempurna karena lebih mudah menumbuhkan keakraban dan kehangatan antara pelaku komunikasi. ${ }^{11}$

Komunikasi bisnis diperlukan bagi orang yang bekerja di organisasi atau perusahaan. Meskipun saat ini sudah ada teknologi (Email, Video Call) yang membantu proses komunikasi bisnis berjalan, namun hal tersebut tidak memberi perasaan puas atas hasil dari interaksi tanpa tatap muka. Oleh karena itu, dalam era perdagangan bebas abad ke-21 para pebisnis tetap merasa perlu untuk bertemu dan saling berunding secara tatap muka. ${ }^{12}$

\section{Strategi Komunikasi Pemasaran}

Strategi komunikasi dalam konteks analisis kebahasaan pertama kali dicetuskan oleh Selinker. Dalam pandangannya, Selinker memasukkan strategi komunikasi sebagai salah satu sumber kesilapan berbahasa. Setiap penutur ingin mitra tuturnya memahami apa yang disampaikannya, tetapi tentu saja tidak semudah yang diduga apalagi dalam situasi percakapan bahasa asing.

Keberadaan sebuah perusahaan ditengah-tengah masyarakat perlu memperhatikan strategi pemasaran dengan menggunakan audit komunikasi. peranan komunikasi dalam pemasaran yaitu menginformasikan dan menawarkan produk kepada masyarakat. Dalam hal ini, perusahaan perlu memiliki strategi yang tepat untuk mendapatkan respon masyarakat.

${ }^{10}$ Syarifuddin S.Gassing dan Suryanto, "public relation",(Yogyakarta:Penerbit Andi Yogyakarta,2016), hlmn

\footnotetext{
${ }^{11}$ Richard D.Lewis, "komunikasi bisnis lintas budaya",(Bandung: PT.Remaja Rosdakarya,2005)h.6

${ }^{12}$ Richard D.Lewis, "komunikasi bisnis lintas budaya",(Bandung: PT.Remaja Rosdakarya,2005)h.7
} 
komunikasi pemasaran memegang peranan yang sangat penting bagi pemasar. Keberadaan komunikasi pemasaran merupakan hal yang mutlak. Konsekuensinya tanpa komunikasi, maka pelanggan, konsumen, maupun masyarakat umum tidak akan mengetahui suatu produk yang dihasilkan oleh masyarakat.

Strategi komunikasi pemasaran juga disebut sebagai juga sebagai bauran komunikasi pemasaran atau bauran promosi. Strategi komunikasi pemasaran yang tepat dapat menghindarkan perusahaan dari keerugian yang disebabkan oleh kegiatan promosi yang tidak efektif dapat dimasukkan dalam bagian dari komunikasi pemasaran. Untuk menyampaikan sesuatu kepada konsumen pada pihak-pihak yang terkait,pemasar kini bisa memilih aktivitas komunikasi tertentu. ${ }^{13}$

Menurut kotler total bauran promosi ( promotion mix ) sebuah perusahaan juga disebut bauran komunikasi pemasaran ( marketing communication mix ) terdiri dari campuran spesifik iklan, public relation, personal selling, promosi penjualana dan alat-alat direct marketing yang digunakan perusahaan untuk mengkomunikasikan nilai pelanggan secara persuasif dan membangun hubungan dengan pelanggan. Ada lima alat promosi utama yang didefinisikan sebagai berikut:

\section{a. Periklanan (Advertising)}

Semua produk penyajian non personal dan promosi ide, barang tau jasa yang dibayar oleh suatu sponsor tertentu.

b. Promosi Penjualan ( Sales Promotion)

Berbagai insentif jangka pendek ;untuk mendorong keinginan mencoba atau membeli suatu produk atau jasa.

c. Hubungan Masyarakat dan Publisitas ( Public Relation dan Publicit ) Berbagai program untuk mempromosikan dan membangun atau melindungi citra perusahaan atau produk individualnya.

d. Penjualan Secara Pribadi ( Personal Selling )

Interaksi langsung dengan satu calon pembeli atau lebih untuk melakukan presentasi, menjawab pertanyaan dan menerima pesanan.

e. Pemasaran Langsung ( Direct Marketing )

\footnotetext{
${ }^{13}$ Eva elvira sitompul, “strategi komunikasi pemasaran dalam upaya meraih konsumen”, jurnal komunikasi bisnis vol 3 no. 1 tahun 2017 , h.4
} 
Penggunaan surat, telepon, faksimili, e-mail dan alat penghubung nonpersonal lain untuk berkomunikasi secara langsung dengan atau mendapatkan tanggapan langsung dari pelanggan tertentu dan calon pelanggan. ${ }^{14}$

Sedangkan menurut Smith marketing communication mix biasanya terdiri atas :

a. Penjualan ( Selling )

Merupakan saluran yang melibatkan dua orang atau lebih yang saling berkomunikasi secara langsung. Komunikasi dilakukan secara tatap muka didepan khalayak, lewat telepon, media atau surat.

b. Iklan (Advertising )

Merupakan saluran media massa yang dilakukan melalui surat kabar, majalah, radio, televisi atau media lainya. Saluran ini merupakan saluran komunikasi non personal, karena ditujukan untuk khalayak luas. Advertising bertujuan untuk menciptakan brand awareness dan membangun citra (image ).

c. Promosi Penjualan ( Sales Promotion )

Adalah penggunaan intensif yang diberikan oleh perusahaan untuk membujuk konsumen membeli satu produk.

d. Pemasaran langsung ( Direct Marketing )

Merupakan bentuk komunikasi langsung dengan khalayak untuk mengetahui respon konsumen.

e. Pemberian Sponsor ( sponsorship)

Yaitu pada suatu kegiatan yang diperkirakan dapat memenuhi tujuan seperti meningkatkan penjualan, meningkatkan reputasi perusahaan, brand iage, brand awareness dan lain-lain.

f. Identitas Korporasi ( Corporate Identity)

Adalah strategi komunikasi yang dilakukan untuk mencapai tujuan jangka panjang perusahaan.

g. Kemasan ( Packiging )

\footnotetext{
${ }^{14}$ Sutisna, “perilaku konsumen dan komunikasi pemasaran”, ((Bandung: PT Remaja Rosdakarya,2003), h.25
} 
Adalah kegiatan untuk mendesain dan membuat bungkus suatu produk. Packaging juga menjadi elemen penting dalam marketing communication mix, karena seringkali keputusan pembelian konsumen dipengarhi oleh pembungkusan ( desain, warna, bentuk ). ${ }^{15}$

h. Email Sebagai media teknologi komunikasi baru

Perbedaan dengan media komunikasi sebelumnya adalah tingkat interaksi dan kecepatan yang dapat dinikmati pengguna untuk menyiarkan pesannya. Semua sistem komunikasi baru yang menggunakan komputer sebagai salah satu komponennya memiliki tingkat interaktivitas yang tinggi yang tidak dapat dilakukan oleh media lama. Kehadiran media baru ini telah mengubah sikap audience yang pasif menjadi interaktif terhadap media. ${ }^{16}$

\section{METODOLOGI}

Penelitian ini merup penelitian lapangan (field research) penelitian lapangan cenderung dilakukan pada situasi sosial yang ada di masyarakat. Penelitian lapangan mengharuskan keterampilan peneliti yang terampil dalam wawancara, pengamatan, melakukan pencatatan data di lapangan dan terampil dalam mengatasi masalah-masalah yang muncul pada saat pengumpulan data dan keabsahan data. ${ }^{17}$ Penelitian ini juga merup penelitian kualitatif. Penelitian kualitatif adalah penelitian yang bersifat deskriptif dan menggun analisis dengan pendekatan induktif. Di dalam ilmu sosial, metode penelitian kualitatif merup metode yang menekankan objek penelitiannya terhadap keunikan manusia atau gejala sosial yang dapat dianalisis dengan metode statistik. ${ }^{18}$

Peneliti memilih jenis penelitian lapangan pada perusahaan PT.Boddia Jaya karena sesuai dengan karakteristik penelitian sosial yang dimana membahas tentang kehidupan masyarakat.

Penelitian ini menggunakan pendekatan penelitian komunikasi pemasaran. Komunikasi pemasaran menjadi salah satu fokus dalam keilmuan Ilmu Komunikasi. Peneliti juga membahas

\footnotetext{
${ }^{15}$ Sutisna, “perilaku konsumen dan komunikasi pemasaran”, ((Bandung: PT Remaja Rosdakarya,2003), h.26

${ }^{16}$ Rahmawati Haruna, "Proximity Dan Kandungan Sosioemosi Isi Pesan Electronic Mail (E-Mail)

Di Mailing List UNHAS-ML”, (Makassar: Universitas Hasanuddin, 2004), H.43

${ }^{17}$ Sugeng Pujileksono, "metode penelitian komunikasi kualitatif", (Malang: Kelompok Intrans Publishing,2015) h.18

${ }^{18}$ Sitti Mania,"metode penelitian dan sosial",,(Makassar:Alauddin University Press, 2013)h.38
} 
tentang aktivitas public relation dan komunikasi pemasaran dalam menganalisis objek sasaran penelitian ini. Namun, peneliti juga membahas mengenai pemasaran, produk, dan transaksi pada dunia bisnis global yang merupakan kajian ilmu ekonomi.

Analisis data dalam penelitian kualitatif adalah aktivitas yang dilakukan secara terusmenerus selama penelitian berlangsung. Dilakukan mulai mengumpulkan data sampai pada penulisan laporan hasil penelitian. ${ }^{19}$

Pada penelitian yang dilakukan peneliti, pengolahan data yang diambil dari catatan lapangan yaitu hasil wawancara bersama beberapa karyawan PT.Boddia Jaya dianalisis oleh peneliti. Kemudian dicocokkan data yang didapatkan di lapangan sudah sesuai dengan pokok permasalahan yang dibahas pada penelitian ini. Jika masih ada kekurangan data yang dibutuhkan, maka peneliti terus menerus melakukan penelitian secara langsung di lapangan sehingga data yang didapat sudah sesuai dengan pokok masalah.

\section{PEMBAHASAN}

Telur ikan terbang atau disebut bayao tuing-tuing adalah produk yang dipasarkan oleh PT.Boddia Jaya baik kepada pembeli dalam negeri maupun luar negeri. Ketika memasarkan produk, ada beberapa strategi komunikasi pemasaran atau cara yang dilakukan untuk memasarkan yang dilakukan PT.Boddia Jaya khusus kepada pihak luar negeri, yaitu:

\section{Periklanan (advertising)}

Strategi komunikasi pemasaran dengan media iklan sangat berpengaruh terhadap penjualan produk. PT.Boddia Jaya juga menerapkan periklanan melalui media online untuk memasarkan telur ikan terbang, selain memasarkan, perusahaan juga berusaha untuk berkomunikasi dengan konsumen (buyer).

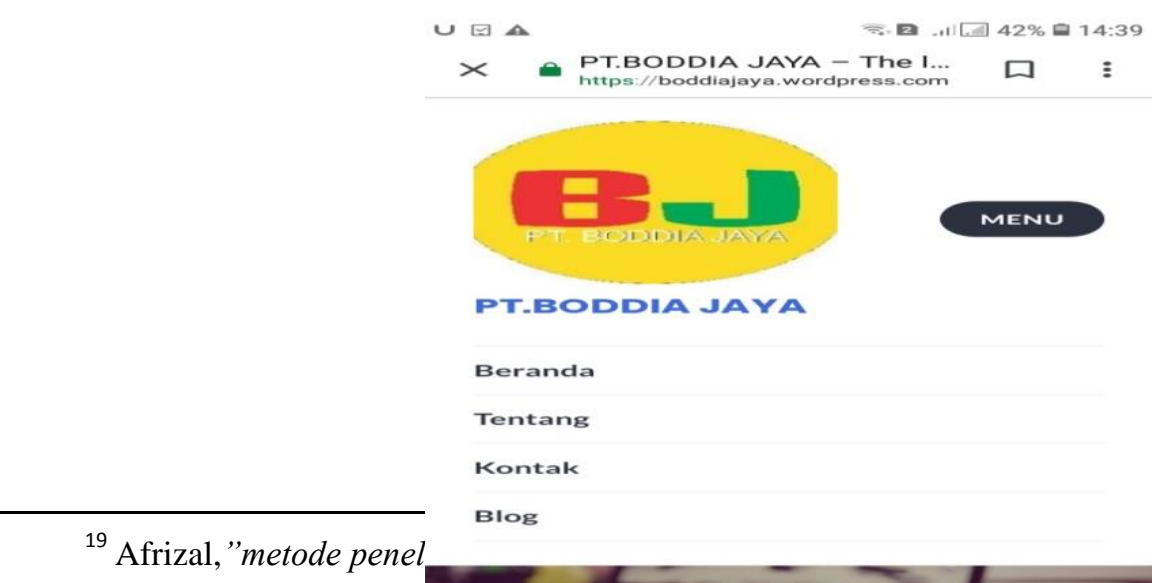




\section{Gambar 4.6 website resmi PT.Boddia Jaya}

PT.Boddia Jaya melakukan promosi pengiklanan melalui media online, yaitu dengan membuat desain secara online kemudian di upload kedalam website resmi PT.Boddia Jaya. Website resmi perusahaan yaitu https://boddiajaya.wordpress.com.

"selain menjadi penghubung antara buyer dengan perusahaan, saya juga bertugas untuk membuat desain untuk keperluan iklan di website resmi PT.Boddia Jaya". ${ }^{20}$
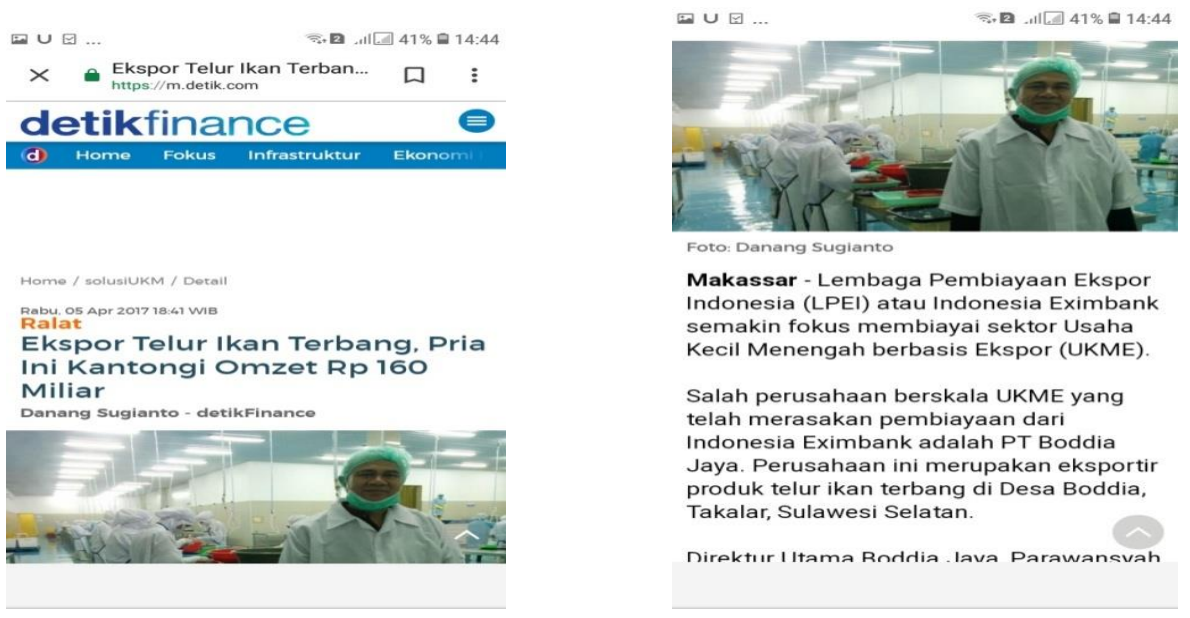

\section{Gambar 4.7 Headline Detik.com}

Berita tersebut bukan hanya sebuah strategi komunikasi pemasaran yang berguna untuk menguntungkan perusahaan PT.Boddia Jaya saja, namun bagi pihak media online pun mendapatkan umpan balik setelah melakukan proses perilisan berita. Pihak PT.Boddia Jaya memberikan secara material pihak media online tersebut sebagai bentuk penghargaan karena membantu komunikasi pemasaran perusahaan.

Media online juga memberitakan hasil penjualan PT.Boddia Jaya. Hal ini sangat membantu perusahaan untuk bisa mendapatkan konsumen (buyer). Seperti yang diberitakan oleh media online detik.com. media online salah satu media yang dimanfaatkan oleh perusahaan ini untuk melakukan periklanan demi mendapatkan buyer (pembeli) baik dari

\footnotetext{
${ }^{20}$ Maryam (25 tahun), divisi marketing PT.Boodia Jaya, wawancara di ruang kerja marketing PT.Boddia Jaya, tanggal 26 juni 2019.
} 
dalam maupun luarnegeri. Strategi komunikasi pemasaran ini sangat berpengaruh bagi penjualan produk, hal ini akan dilakukan lagi pada tahun berikutnya, untuk meningkatkan jumlah keuntungan dari hasil penjualan telur ikan terbang perusahaan.

2. Indirect marketing (by email)

Strategi indirect marketing yang dilakukan pihak PT.Boddia Jaya mencakup 4P (product,price,place,promotion). Salah satu bentuk komunikasi pemasaran perusahaan yaitu komunikasi tidak langsung dengan buyer luarnegeri melalui Email. Strategi kedua ini dilakukan oleh divisi dokumen ekspor yaitu Maryam. Jadi, aktivitas yang dilakukan hanya duduk di depan komputer sampai pada tahap kontrak antara perusahaan dan buyer luarnegeri.

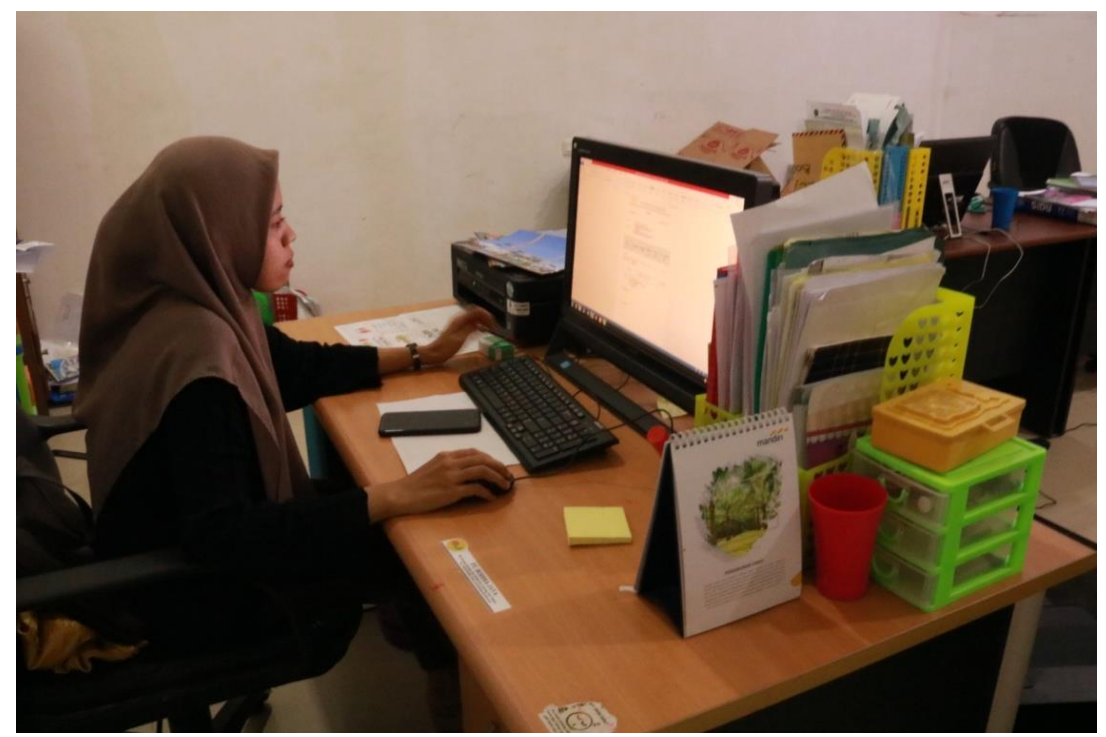

\section{Gambar 4.8 aktivitas komunikasi pemasaran divisi marketing}

Proses komunikasi yang dilakukan pihak perusahaan dengan buyer luarnegeri yaitu:

Pertama, melakukan promosi dengan mengirimkan dokumen lengkap tentang produk telur ikan tersebut. Promosi yang dilakukan berupa membuat desain produk dengan menarik. Hal ini dilakukan untuk menarik perhatian calon buyer sehingga bisa memesan produk telur ikan tersebut.Kedua, jika buyer merespon dan ingin melakukan pemesanan produk, hal yang pertama adalah penentuan harga yang diberikan oleh perusahaan kepada buyer. Jika buyer sudah menyetujui harga yang diberikan. Maka selanjutnya adalah pembuatan dokumen kontrak antara kedua belahpihak.Ketiga, jika sudah melakukan pemesanan, pihak buyer melakukan kunjungan untuk melihat produk yang akan dipesan. Hal ini merupakan 
sebuah strategi perusahaan agar pihak buyer lebih percaya terhadap keaslian dan kualitas produk. Kunjungan yang dilakukan oleh buyer ke perusahaan untuk memastikan bahwa produk yang akan dipesan memiliki mutu dan kualitas yang baik. Keempat, adalah proses pengiriman produk ke negara asal buyer. Pengiriman produk bisa dilakukan jika sudah memenuhi syarat dan dokumen ekspor. Proses pengiriman produk diikuti dengan proses transaksi atau pembayaran setelah melakukan pemesanan produk. ${ }^{21}$

\section{Packaging (pengemasan)}

Adalah kegiatan untuk mendesain dan membuat bungkus suatu produk. Packaging juga menjadi elemen penting dalam marketing communication mix, karena seringkali keputusan pembelian konsumen dipengarhi oleh pembungkusan ( desain, warna, bentuk ). Proses pengemasan yang dilakukan oleh PT.Boddia Jaya merupakan salah satu strategi komunikasi pemasaran yang sudah diterapkan sejak awal penjualan produk tersebut.

"telur itu di packing menggunakan master carton. Master carton itu berupa pembungkus berbahan plastik dan karton dengan ukuran besar untuk dimasukkan kedalam kontainer. Isi per kontainer itu sampai 20ton,". 22

Proses packaging dilakukan selama beberapa jam bahkan bisa menghabiskan waktu seharian. Quality control bisa mengawasi hingga 30 karyawan yang bekerja dari proses pembersihan telur ikan hingga proses terakhir dari produksi yaitu pengemasan (packaging). PT.Boddia Jaya hampir tidak pernah mengalami kesulitan dalam proses packaging, segala persiapan telah disiapkan di ruangan produksi telur ikan terbang yang di pasarkan oleh pihak perusahaan.

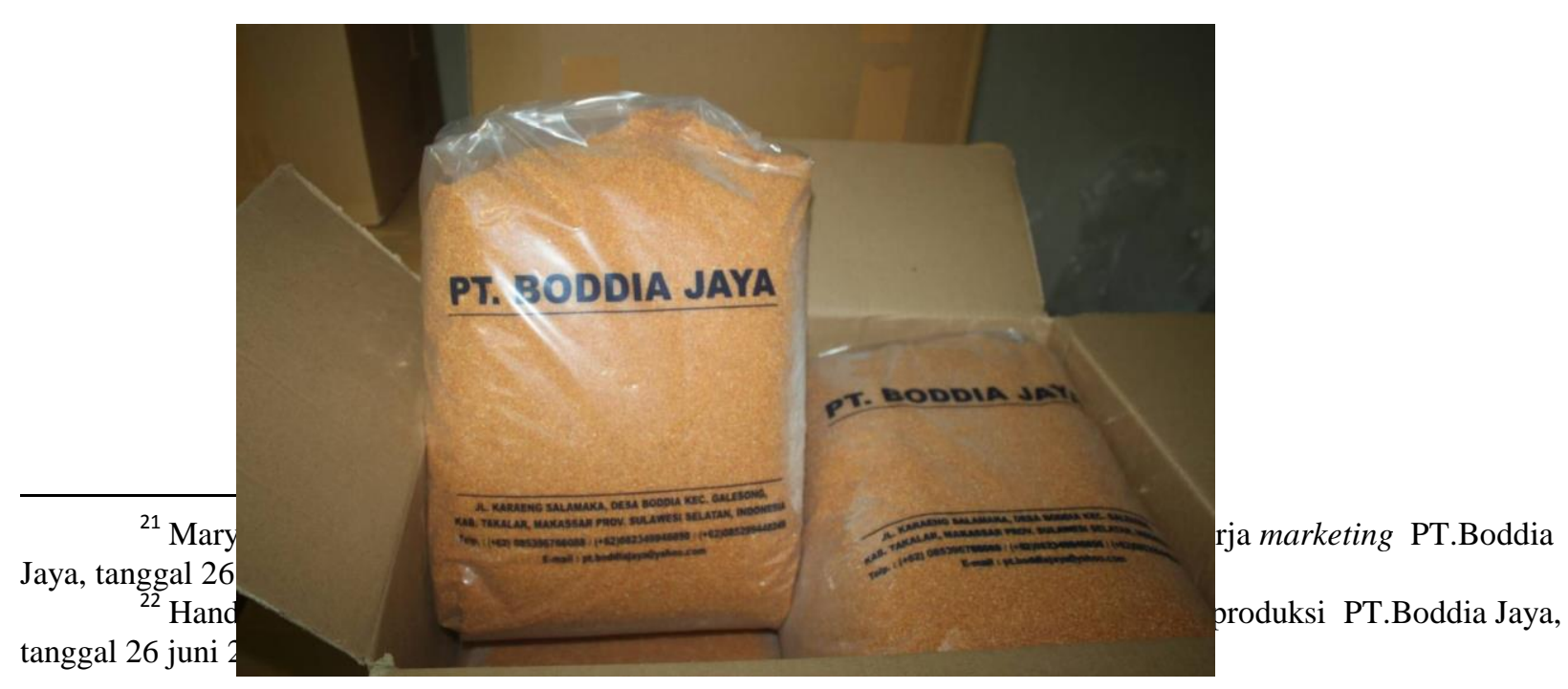




\section{Gambar 4.9 packaging produk}

Packaging produk PT.Boddia Jaya tidak hanya difungsikan pada saat proses pemasaran. Tetapi, packaging produk juga dilakukan demi melindungi telur ikan agar tidak berjamur sehingga mengurangi kualitas dan harga produk. Sebelum melakukan proses packaging, bagian produksi melakukan riset terlebih dahulku tentang bahas dan warna packaging produk yang akan dipasarkan kepada buyer. Hal ini dilakukan agar tingkat pemasaran produk telur ikan terbang jauh lebih luas (ekspor).

Packaging ditempatkan sebagai salah satu alat yang paling berharga dalam strategi komunikasi pemasaran PT.Boddia Jaya. Manajemen packaging produk telur ikan ini memerlukan analisis lebih detail sehingga berdampak pada pemesan buyer. Packaging produk telur ikan terbang juga menjadi identitas perusahaan sehingga memperluas nilai produk dan perusahaan PT.Boddia Jaya. Packaging menjadi strategi kedua yang dijadikan dalam berkomunikasi dengan buyer. Packaging dilakukan bersamaan dengan periklanan dan indirect marketing.

Meskipun strategi komunikasi pemasaran yang dilakukan PT.Boddia Jaya hanya tiga macam. Namun hal tersebut tidak keluar dari teori yang telah dibahas pada bab 2 . Perusahaan ini melakukan aktivitas public relations yang dilakukan untuk pemasaran perusahaan. Dalam pembahasan PR, salah satu fungsi PR itu sendiri adalah pemasaran. Meskipun pada struktur organisasi tidak disebutkan divisi public relations, namun PT.Boddia Jaya berhasil mendapat keuntungan dengan mengandalkan aktivitas public relstions itu sendiri.

Ruang lingkup strategi komunikasi pemasaran PT.Boddia Juga hampir sama dengan teori yang dibahas sebelumnya, yaitu pemasaran perusahaan ini mencakup merencanakan dan mengembangkan sebuah produk, kemudian Memutuskan cara terbaik untuk menentukan harga,mempromosikan dan mendistribusikan produk.

Meskipun Kotler menyebutkan bahwa ada lima alat promosi pemasaran pada perusahaan, namun PT.Boddia jaya hanya menerapkan tiga dari kelima alat tersebut. Hal ini dikarenakan, melihat 
dari segi eksternal perusahaan yang kebanyakan masyarakat desa. Jadi untuk hal-hal tertentu seperti E-marketing hanya diterapkan pada buyer luarnegeri.

\section{E. KESIMPULAN}

Strategi komunikasi pemasaran PT.Boddia Jaya dalam menjalin kerjasama dengan pihak luar negeri, yaitu Pertama, PT.Boddia Jaya melakukan pengiklanan melalui media online, yaitu dengan membuat pamflet online kemudian diupload kedalam website resmi PT.Boddia Jaya Website resmi perusahaan yang dijadikan sebagai alat untuk periklanan yaitu https://boddiajaya.wordpress.com. Kedua, media online salah satu media yang dimanfaatkan oleh perusahaan ini untuk melakukan periklanan demi mendapatkan buyer (pembeli) baik dari dalam maupun luarnegeri. Ketiga, Strategi indirect marketing yang dilakukan pihak PT.Boddia Jaya mencakup 4P (product,price,place,promotion). Salah satu bentuk komunikasi pemasaran perusahaan yaitu komunikasi tidak langsung dengan buyer luar negeri melalui Email. Keempat, Packaging ditempatkan sebagai salah satu alat yang paling berharga dalam strategi komunikasi pemasaran PT.Boddia Jaya. packaging produk telur ikan ini memerlukan analisis lebih detail sehingga berdampak pada pemesan buyer. Packaging ditempatkan sebagai salah satu alat yang paling berharga dalam strategi komunikasi pemasaran PT.Boddia Jaya. Manajemen packaging produk telur ikan ini memerlukan analisis lebih detail sehingga berdampak pada pemesan buyer.

\section{DAFTAR PUSTAKA}

Al-Qur'an diambil dari https://tafsirq.com yang telah dicocokkan oleh calon peneliti di Kementrian Agama RI, Al-Qur'an dan Terjemahan (Bandung: CV. Mikraj Khazanah Ilmu, 2014),

Budyatna, Muhammad “Komunikasi Bisnis Silang Budaya”,(Jakarta:Kencana,2012),

Bungin, Burhan, "penelitian kualitatif”, (Jakarta: Kencana,2007),

Gassing ,Syarifuddin S. dan Suryanto,"Public Relation”,(Yogyakarta:Penerbit Andi Yogyakarta,2016),

Haruna, Rahmawati "Proximity Dan Kandungan Sosioemosi Isi Pesan Electronic Mail (E-Mail) Di Mailing List UNHAS-ML”, (Makassar: Universitas Hasanuddin, 2004),

Hefni ,Harjani, “Komunikasi Islam”,(Jakarta: Prenadamedia Group,2015),

Jain, C Subhash, “Manajemen Pemasaran Internasional”, (Jakarta: Penerbit Erlangga,2001),

Kementrian Agama RI, Al-Qur'an dan Terjemahan (Bandung: CV. Mikraj Khazanah Ilmu, 2014), 
Kriyantono, Rachmat, "Teori-Teori Public Relations Perspektif Barat Dan Lokal", (Jakarta: Kencana,2014),

Lewis, D. Richard,“Komunikasi Bisnis Lintas Budaya”(Bandung: PT.Remaja Rosdakarya,2005,

Linggar,M Anggoro,"Teori Dan Profesi Kehumasan (Serta Aplikasinya Di Indonesia)",(Jakarta:PT Bumi Aksara,2008),

Mania, Sitti”Metode Penelitian Dan Sosial”,(Makassar:Alauddin University Press, 2013),

Morissan, “Manajemen Public Relation”,(Jakarta:Kencana,2010),

Muliadi,"Komunikasi Islam",(Makassar: Alauddin University Press,2012),

Pujileksono, Sugeng “metode penelitian komunikasi kualitatif”, (Malang: Kelompok Intrans Publishing,2015),

Ruslan,Rosady “Metode Penelitian Public Relation Dan Komunikasi,Ed.1”(Jakarta:PT.Raja Grafindo Persada,2008),

Sugiono,"Metodeologi Penelitian Adminitrasi",(Jakarta: CV.Alfabeta,2006),

--------, "Metode Penelitian Kuantitatif Kualitatif",(Bandung:Alpabeta,2009),

Suprawoto,"Government public relations:perkembangan dan praktik di Indonesia", (Jakarta:Prenadamedia Group,2018),

Suryanto, "pengantar ilmu komunikasi", (Jawa Barat: CV Pustaka Setia:2015),

Sutisna, "Perilaku Konsumen Dan Komunikasi Pemasaran", (Bandung: PT Remaja Rosdakarya,2003),

Priyono ,Herien, “Public Relation Sebagai Strategic Tools”,(Jogjakarta:UII Press,2005), 